\title{
PERKIRAAN KONSUMSI ENERGI LISTRIK 2013 HINGGA 2030 ACEH TAMIANG
}

\author{
Rahmad Purnama ${ }^{1}$, Ahmad Agus Setiawan², Suhanan ${ }^{3}$ \\ ${ }^{1}$ Magister Teknik Sistem Fakultas Teknik, Universitas Gadjah Mada. \\ ${ }^{2}$ Teknik Fisika Fakultas Teknik, Universitas Gadjah Mada \\ ${ }^{3}$ Magister Teknik Sistem Fakultas Teknik, Universitas Gadjah Mada
}

\begin{abstract}
Aceh Tamiang is the province of Aceh. The use of electrical energy is still not resolved in this case because of the lack of appropriate policies that can be taken because there is still no research how the amount of electrical energy consumption in Aceh Tamiang. the research method used is a model based approach to End Use of data population and households, the data GDP at constant prices, and consumption of electrical energy. All data is sourced from related agencies such as Bappeda Aceh Tamiang Data PLN Kuala Simpang branch. Forecasting electric energy consumption in Aceh on five sectors is the year 2013 was $48.8 \mathrm{GWh}$, while, in 2030 total energy consumption reached $76.5 \mathrm{GWh}$, this is an increase of 63.7 percent. The household sector accounted for the largest increase in consumption compared with other sectors for each year.
\end{abstract}

Keywords: Forecasting, Consumption, Electric, Aceh Tamiang.

Abstrak

Aceh Tamiang berada Provinsi Aceh. Penggunaan energi listrik hingga saat ini masih belum teratasi hal tersebut dikarenakan oleh belum ada kebijakan yang tepat yang dapat diambil karena masih belum ada penelitan berapa jumlah konsumsi energi listrik di Aceh Tamiang. metode penelitian yang digunakan adalah model pendekatan End Use berdasar data jumlah penduduk dan rumah tangga, data PDRB atas dasar harga konstan, dan konsumsi energi listrik. Semua data tersbut bersumber dari dinas terkait seperti Bappeda Aceh Tamiang data PLN cabang Kuala Simpang. Peneltian ini, Total Konsumsi energi listrik di Kabupaten Aceh pada lima sektor adalah pada Tahun 2013 adalah 48,8 GWh, Sedangkan, pada Tahun 2030 total konsumsi energi mencapai $76,5 \mathrm{GWh}$, hal ini terjadi peningkatan sebesar 63,7 persen. Sektor rumah tangga menyumbang peningkatan konsumsi yang terbesar dibandingkan dengan sektor yang lain untuk setiap tahunnya.

Kata kunci: Perkiraan, Konsumsi, Listrik, Aceh Tamiang.

\section{Pendahuluan}

Aceh Tamiang berada di Provinsi Aceh. Kebijakan pemerintah tentang konsumsi energi listrik belum tetatasi, bukti dari kebijakan yang tidak teratasi adalah masih seringnya terjadi pemadaman listrik dan bahkan ada kawasan yang masih belum memiliki listrik. Hal 
tersebut, karena perencanaan tentang berapa daya listrik yang dibutuhkan (demand) masih belum dilakukan.

Pemerintah pusat dalam hal ini Direktorat Energi Sumber Daya Mineral dan Pertambangan dibawah naungan Badan Perencanaan Pembangunan Nasional (BAPPENAS) telah mengeluarkan Kebijakan Energi Nasional (KEN), Rancangan Umum Energi Nasional (RUEN), dan Rancangan Umum Energi Daerah-Propinsi (RUED-P) untuk keselarasan. BAPPENAS menyatakan bahwa RUEN dan RUED dilakukan untuk pemetaan kebutuhan energi khususnya listrik. Hal ini ditegaskan oleh Keputusan Menteri Energi Dan Sumber Daya Mineral Nomor 2682 K/21/MEM/2008 tentang Rencana Umum Ketenagalistrikan Nasional (RUKN) 2008 s.d. 2027. RUKN berisikan tentang Pemda membuat perkiraan kebutuhan energi listrik untuk daerahnya minimal kurun waktu 15 tahun ke depan.

\section{Tinjauan Pustaka}

\subsection{Laju Pertumbuhan}

Anugerah (2013) menghitung laju pertumbuhan penduduk dengan menggunakan persamaan berikut ini.

$$
r=\left(\frac{P t}{P 0}\right)^{\frac{1}{t}-1} \times 100
$$

Keterangan :

r : laju pertumbuhan.

Pt : Jumlah penduduk tahun terakhir

P0 : Jumlah penduduk pada tahun dasar

$\mathrm{t} \quad$ : selisih tahun terakhir dengan tahun dasar.

Persamaan laju pertumbuhan penduduk diatas juga digunakan untuk menghitung laju pertumbuhan pelanggan rumah tangga. Pada sektor rumah tangga hal yang berpengaruh juga jumlah rasio elektrifikasi atau rumah tangga yang sudah menggunakan listrik.

\subsection{Konsumsi Energi Listrik.}

Menurut Suhono (2010) penjelasan dari buku User Guide for Version 2011 memberi gambaran permintaan energi dapat dihitung sebagai hasil perkalian antara aktifitas total pemakaian dengan intensitas energi dari setiap cabang teknologi (technology branch). Persamaan permintaan konsumsi energi listrik adalah sebagai berikut.

$$
\mathrm{D}_{\mathrm{b}, \mathrm{s}, \mathrm{t}}=\mathrm{TA}_{\mathrm{b}, \mathrm{s}, \mathrm{t}} \times \mathrm{EI}_{\mathrm{b}, \mathrm{s}, \mathrm{t}}
$$

Keterangan :

$$
\begin{aligned}
& \text { D }: \text { Permintaan (Demand), } \\
& \text { TA }: \text { aktivitas total (Total Activity), } \\
& \text { EI }: \text { Intensitas Energi (Energy Intensity), } \\
& \text { b } \text { : "cabang" (branch), } \\
& \text { s : tipe skenario (scenario), } \\
& \text { t : tahun dilakukan perhitungan (mulai tahun dasar hingga tahun } \\
& \\
& \text { akhir perhitungan). }
\end{aligned}
$$




\subsection{Faktor yang mempengaruhi pertumbuhan konsumsi energi listrik adalah.}

\section{a. Rumah Tangga}

Konsumen energi listrik pada umumnya digunakan oleh sektor rumah tangga. Pada suatu kawasan penggunanaan energi listrik di pengaruhi oleh besarnya pengguna listrik (rasio elektrifikasi).

\section{b. Ekonomi.}

Pertumbuhan ekonomi menjadi faktor yang cukup signifikan pada pola hidup untuk mengkonsumsi energy, karena semakin tinggi pendapatan masyarakat, maka kebutuhan akan energi listrik juga akan meningkat. PDRB dapat menjadi salah satu tolak ukur kemakmuran suatu daerah untuk sektor industri, publik, sosial dan bisnis.

\section{c. Pengembangan Kawasan}

Dengan meningkatnya perekonomian dan aktifitas ekonomi lainnya akan menyebabkan peningkatan konsumsi energi. Termasuk juga kebutuhan akan energi listrik, Pengembangan wilayah suatu daerah atau kawasan dapat dilihat dari RPJM (Rencana Pembangunan Jangka Menengah) atau RPJP (Rencana Pembangunan Jangka Panjang) yang ada di setiap kabupaten atau kota.

Perhitungan perkiraan konsumsi energi listrik digunakan 4 model pedekatan.

1. Pendekatan End Use.

Pendekatan end use adalah pendekatan perkiraan berdasarkan data konsumsi energi yang telah digunakan.

2. Pendekatan ekonometika.

Ekonometrik merupakan pengukuran teori ekonomi melalui metode statistik, kelebihan model ekonometrik terletak pada kemampuannya untuk menangani saling ketergantungan (interdependensi). Model ini kemudian menjadi prototype bagi pengembangan sebagian besar model-model ekonometrik yang lain, termasuk dalam bidang energi

3. Pendekatan pedekatan proses.

Pendekatan proses yang dilalui mulai dari ekstrasksi sumber energi, penyulingan, konversi, transportasi, penimbunan, transmisi dan distribusi. Kelemahan model ini adalah tidak adanya faktor ekonomi sehingga pendekatan model ini tidak dapat digunakan sekaligus untuk kebijakan di bidang ekonomi. Keunggulannya, model ini mengakomodasi bahan bakar tradisional dan dapat digunakan dengan perhitungan sederhana.

\section{Pendekatan Trend.}

Pendekatan trend dilakukan dengan melakukan proyeksi berdasarkan data historis di masa lalu. Data.

\section{Metodologi Penelitian}

Alur penelitian adalah seperti pada Gambar 1. Penelitian ini dilakukan dengan memetakan intensitas energi listrik untuk sub sektor rumah tangga, industri, bisnis, publik dan sosial, dan memperkirakan konsumsi energi listrik untuk masa yang akan datang. Pada penelitian perkiraan konsumsi energi listri di aceh tamiang membutuhkan data sebagai berikut.

1. Data jumlah penduduk dan rumah tangga. 
2. Data PDRB atas dasar harga konstan.

3. Konsumsi Energi Listrik.

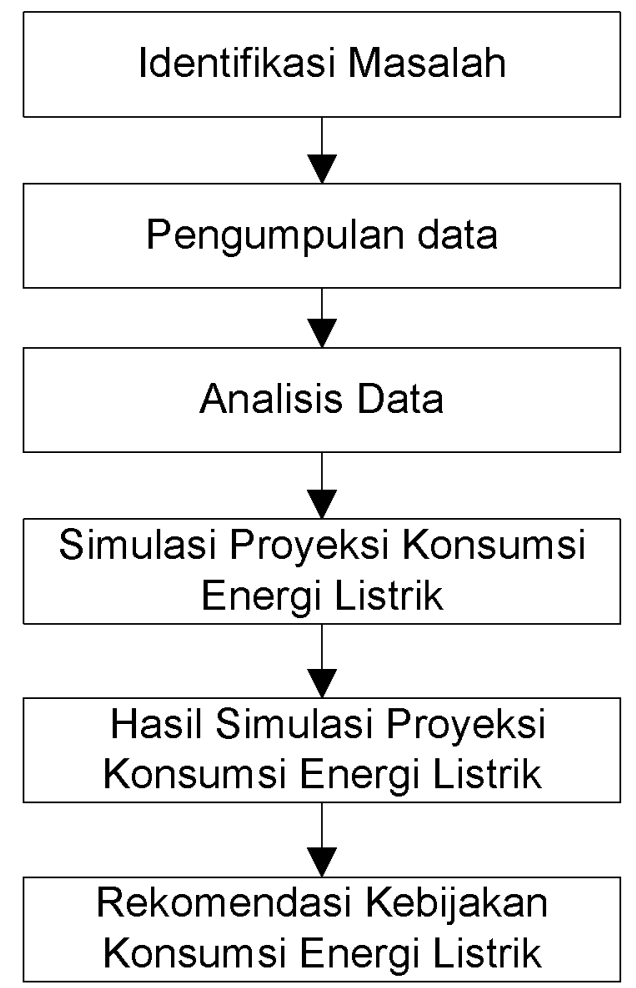

Gambar 1. AlurPenelitian

Penelitian ini menggunakan model pendekatan End Use, dan asumsi yang digunakan seperti kondisi sosial, ekonomi, politik dan keamanan akan berlangsung secara normal baik di dalam maupun luar negeri, dengan kata lain tidak ada masalah-masalah seperti peperangan, krisis moneter dan gejolak politik yang akan menghambat laju pertumbuhan penduduk dan ekonomi.

\section{Hasil Penelitian}

Konsumsi energi listrik dipengaruhi oleh pertumbuhan rumah tangga dan ekonomi. PDRB harga konstan 2000 menjadi parameter dari pertumbuhan sektor bisnis, industri, publik dan sosial karena sektor ini berkaitan erat dengan pertumbuhan ekonomi. Sedangkan untuk sektor rumah tangga menggunakan tolok ukur pertumbuhan dari rumah tangga itu sendiri. Dari hasil pengolahan data menggunakan perangkat lunak/software LEAP diperoleh total dari konsumsi energi listrik seperti pada Tabel 1 berikut ini.

Tabel 1. menunjukan peningkatan konsumsi energi listrik dari tahun ke tahun peningkatan. Peningkatan konsumsi listrik dari Tahun 2013 hingga 2030 mencapai 63\% bentuk peningkatan dapat dilihat pada Gambar 2.

Berdasarkan Gambar 2 menunjukan konsumsi listrik terbesar adalah sektor rumah tangga, hal ini dipengaruhi oleh rasio perrtumbuhan penduduk yang terus mengalami peningkatan, namun, bagaimana konsumsi pada setiap sektor adalah sebagai berikut. 
a. Konsumsi listrik sektor rumah tangga Tahun 2014 adalah 29.964.807 Kwh atau 30 Gwh. Kemudian, pada Tahun 2030 hasil perkiraan konsumsi energi listrik mencapai 38.995.343 Kwh atau $39 \mathrm{Gwh}$. Hal ini, dipengaruhi oleh pertumbuhan rumah tangga yang mencapai $1,66 \%$ pertahun dengan jumlah rumah tangga mencapai 81.894 rumah tangga pada tahun 2030.

Tabel. 1 Konsumsi Energi Listrik

\begin{tabular}{|l|l|c||}
\hline No & Tahun & $\begin{array}{c}\text { Konsumsi Energi Listrik satuan } \\
\text { GigaWatt-hours }\end{array}$ \\
\hline \hline 1 & 2013 & 48,8 \\
\hline 2 & 2014 & 48,8 \\
\hline 3 & 2015 & 50,1 \\
\hline 4 & 2016 & 51,4 \\
\hline 5 & 2017 & 52,8 \\
\hline 6 & 2018 & 54,2 \\
\hline 7 & 2019 & 55,7 \\
\hline 8 & 2020 & 57,2 \\
\hline 9 & 2021 & 58,8 \\
\hline 10 & 2022 & 60,5 \\
\hline 11 & 2023 & 62,2 \\
\hline 12 & 2024 & 64 \\
\hline 13 & 2025 & 65,9 \\
\hline 14 & 2026 & 67,8 \\
\hline 15 & 2027 & 69,8 \\
\hline 16 & 2028 & 72 \\
\hline 17 & 2029 & 74,2 \\
\hline 18 & 2030 & 76,5 \\
\hline & & \\
\hline
\end{tabular}

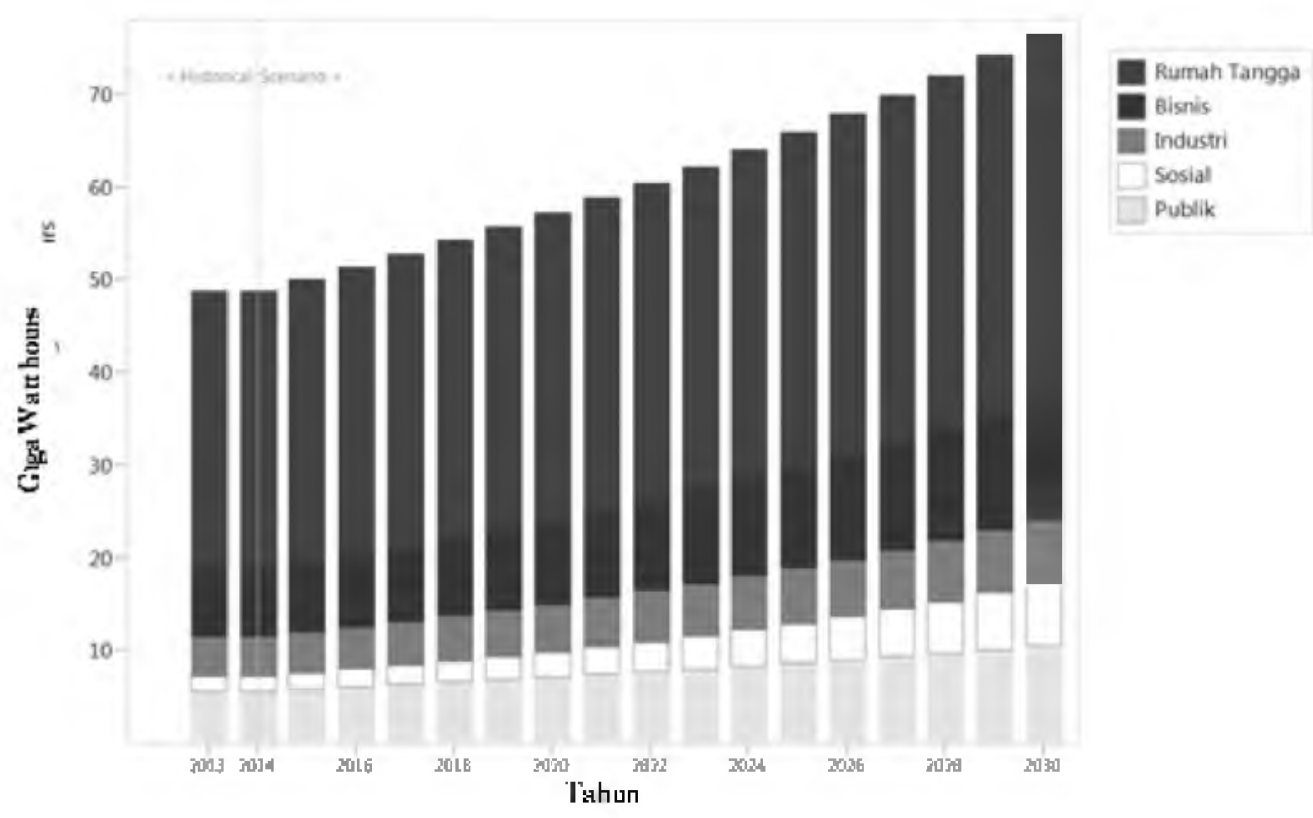


Gambar 2. Perkiraan konsumsi Energi Listrik Aceh Tamiang dari Tahun 2013 hingga 2030

b. Konsumsi listrik sektor Industri Tahun 2014 adalah $4.340 .526,40 \mathrm{Kwh}$ atau 4,5 Gwh. Kemudian, pada Tahun 2030 hasil perkiraan konsumsi energi listrik mencapai 7,018.868.45 Kwh atau $7 \mathrm{Gwh}$. Hal ini, dipengaruhi oleh pertumbuhan ekonomi di bidang Industri yang mencapai 3,14\% pertahun dengan mencapai Rp.178.328.000,94 (Seratus Tujuh Puluh Delapan Juta Tiga Ratus Dua Puluh Delapan Ribu Koma Sembilan Puluh Empat Rupiah), pada Tahun 2030.

c. Konsumsi listrik sektor bisnis Tahun 2014 adalah $7.218 .767,1 \mathrm{Kwh}$ atau 7,5 Gwh. Kemudian, pada Tahun 2030 hasil perkiraan konsumsi energi listrik mencapai 11.838.510,5 Kwh atau $12 \mathrm{Gwh}$. Hal ini, dipengaruhi oleh pertumbuhan ekonomi di bidang Bisnis yang mencapai 3,14\% pertahun dengan mencapai Rp 363.925.000,93 (Tiga Ratus Enam Puluh Tiga Juta Sembilan Ratus Dua Puluh Lima Ribu Koma Sembilan Tiga Rupiah) pada Tahun 2030.

d. Konsumsi listrik sektor sosial Tahun 2014 adalah $1.587 .719,27 \mathrm{Kwh}$ atau 1,6 Gwh. Kemudian, pada Tahun 2030 hasil perkiraan konsumsi energi listrik mencapai 2.950.975,58 Kwh atau $3 \mathrm{Gwh}$. Hal ini, dipengaruhi oleh pertumbuhan ekonomi di bidang sosial yang mencapai 3,95\% pertahun dengan mencapai 19.184.000,60 (Sembilan Belas Juta Seratus Delapan Puluh Empat Ribu Koma Enam puluh Rupiah) pada tahun 2030.

e. Konsumsi listrik sektor publik Tahun 2014 adalah 5.653.356,9 Kwh atau 5,8 Gwh. Kemudian, pada Tahun 2030 hasil perkiraan konsumsi energi listrik mencapai 23.870.074,4 Kwh atau $24 \mathrm{Gwh}$. Hal ini, dipengaruhi oleh pertumbuhan ekonomi di bidang publik yang mencapai 9,42\% pertahun dengan mencapai Rp. 767.033.000,24 (Tujuh Ratus Enam Puluh Tujuh Juta Tiga Puluh Tiga Ribu Koma Dua Puluh Empat Rupiah) pada Tahun 2030.

\section{Kesimpulan}

Total Konsumsi energi listrik di Kabupaten Aceh pada lima sektor adalah pada Tahun 2013 adalah 48,8 GWh, Sedangkan, pada Tahun 2030 total konsumsi energi mencapai 76,5 GWh, sektor rumah tangga menyumbang peningkatan konsumsi yang terbesar dibandingkan dengan sektor yang lain untuk setiap tahunnya. 


\section{Daftar Pustaka}

Park Bae nyun, 2013, An analysis of long-term scenarios for the transition to renewable energy in the Korean electricity sector, Energy Policy, Elsevier.

PLN Cabang Kuala Simpang, 2013, Data Konsumsi energi listrik Aceh Tamiang, PLN Aceh Tamiang.

Prihandita Ria Septiana, 2014, Proyeksi Konsumsi Energi Kota Yogyakarta, Tesis, Program Pascasarjana Fakultas Teknik Universitas Gajah Mada.

Undang-Undang No 30 tahun 2009 Tentang Ketenaga Listrikan.

Wijaya, E.M, Ridwan M.K, 2009, Modul Pelatihan Perencanaan Energi, Jurusan Teknik Fisika Fakultas Teknik Universitas Gajah Mada.

Yophy Huang dkk, 2011, The long-term forecast of Taiwan's energy supply and demand: LEAP model applacation, Energy Policy, Elsevier. 
Rahmad Purnama, Ahmad Agus Setiawan, Suhanan 